Keilin, D. \& Hartree, E. F. (1937). Proc. Roy. Soc. B, 122, 298.

Keltch, A. K. \& Clowes, G. H. A. (1951). Proc. Soc. exp. Biol., N.Y., 77, 831.

Kennedy, E. P. (1952). Fed. Proc. 11, 239.

Lamerton, L. F. \& Hariss, E. B. (1951). Brit. med. J. 2, 932.

Lehninger, A. L. (1949). J. biol. Chem. 178, 625.

Lehninger, A. L. (1951). Phosphorus Metabolism, 1. Ed. by McElroy, W. D. \& Glass, H .B. Oxford: Johns Hopkins Press.

Lipschitz, M. A., Potter, V. R. \& Elvehjem, C. A. (1938). J. biol. Chem. 123, 267.

McKibbin, J. M. \& Taylor, W. E. (1949). J. biol. Chem. 178, 17.

Maleci, A. (1950). Arch. Fisiol. 50, 18.

Morrison, L. R. (1946). Arch. Neurol. Psychiat., Chicago, $55,1$.
Ochoa, S. (1941). J. biol. Chem. 138, 751.

Ochoa, S. (1944). J. biol. Chem. 155, 87.

Peters, R. A. (1936). Biochem. J. 30, 2206.

Peters, R. A. \& Sinclair, H. M. (1933). Biochem. J. 27, 1677.

Peters, R. A. \& Wakelin, R. W. (1938). Biochem. J. 32, 2290.

Peterson, E. A. \& Greenberg, D. M. (1952). J. biol. Chem. 194, 359.

Popják, G. \& Muir, H. (1950). Biochem. J. 46, 103.

Robertson, W. B. (1942). Science, 96, 93.

Schachner, H., Fries, B. A. \& Chaikoff, I. L. (1942). J. biol. Chem. 146, 95.

Schaltenbrand, S. \& Schorn, P. (1948). Dtsch. Z. Nervenheilk. 159, 408.

Slater, E. C. \& Cleland, K. W. (1953). Biochem. J. 53, 557.

Sloane-Stanley, G. H. (1952). Symp. biochem. Soc. 8, 44.

\title{
The Amino Acid Composition of Salmine
}

\author{
By M. C. CORFIELD AND A. ROBSON \\ Wool Industries Research Association, Torridon, Headingley, Leeds
}

(Received 24 February 1953)

During recent years several authors have investigated the amino acid composition of salmine, employing a variety of classical and modern methods of analysis. Reference may be made to Tristram (1947), Hamer \& Woodhouse (1949), Block, Bolling, Gershon \& Sober (1949), Velick \& Udenfriend (1951) and Mills (1952). The analyses of these authors clearly show that salmine contains only the seven amino acids: glycine, valine, alanine, isoleucine, proline, serine and arginine; Velick \& Udenfriend (1951) identified a small amount of glutamic acid in their salmine hydrolysates but regarded it as an impurity. A careful examination of all these analytical data shows that, whereas there is good agreement for the glycine and arginine contents of salmine, there are fairly wide differences in the estimated amounts of the other five amino acids.

Blackburn \& Robson (1953) found that the ratio of isoleucine to valine in salmine hydrolysates was almost exactly $1: 3$; a finding which agrees fairly well with that of Block et al. (1949), but not with the other analyses. We have, therefore, carried out a full analysis of our salmine sulphate sample to see if its amino acid composition is significantly different from that of samples hitherto analysed.

\section{EXPERIMENTAL}

\section{Chromatographic techniques}

The amino acid separations were carried out by chromatography on starch columns $30 \mathrm{~cm}$. in length and $0.9 \mathrm{~cm}$. in diameter by the methods of Stein \& Moore (1948). Two samples of starch were used, one being manufactured by Gordon Slater Ltd., Manchester, and the other (labelled Jalan A48) supplied by James Laing \& Co. Ltd., Manchester. Both samples gave satisfactory resolution of the amino acids but the Jalan A48 starch was the finer of the two, a $30 \mathrm{~cm}$. column having a flow rate of $1.3 \mathrm{ml} . / \mathrm{hr}$. under $15 \mathrm{~cm} . \mathrm{Hg}$ pressure, whilst the Gordon Slater starch gave a flow rate of $1.5 \mathrm{ml}$./hr. under a pressure of $6 \mathrm{~cm}$. Hg. The Jalan A48 starch, however, had a much higher column blank than the Gordon Slater starch, whose blank was equal to that of the developing solvent.

During early work with starch chromatograms it became apparent that the optimum load of $3 \mathrm{mg}$. of amino acids quoted by Stein \& Moore (1948) was not sufficient to afford accurate analyses of isoleucine and alanine in salmine as they each only constitute about $1 \%$ of the protamine. It was found, in common with Stein \& Moore, that loads greater than $3 \mathrm{mg}$. of amino acids caused flattening and broadening of the peaks, and prevented separation of proline from alanine and of serine from glycine. By modifying the method of applying the amino acid mixture to the column, however, we found that we could increase the load up to $8 \mathrm{mg}$. of amino acids without impairing the resolution of isoleucine, valine, proline and alanine. A suitable portion of amino acid mixture or protein hydrolysate was delivered from a microburette on to a circle of Whatman no. 3 filter paper $(0.9 \mathrm{~cm}$. diam.) and dried in a stream of warm air. After the surface of the starch column had been carefully dried and tamped, the paper circle was dropped on to it and pressed gently into place with a stainless-steel rod. $0.5 \mathrm{ml}$. of developing solvent was run over the end of the rod, allowed to drain on to the column surface, and driven in under pressure. A further two $0.5 \mathrm{ml}$. amounts of solvent were similarly added. The column was then prepared for development and transferred to the fraction cutter, which was similar in design to that used by Stein \& Moore (1948). 
Three different types of chromatograms were employed in the analysis of salmine hydrolysates. Accurate estimations of isoleucine, valine, proline and alanine were obtained using columns loaded with $8 \mathrm{mg}$. of salmine hydrolysate, and developed with a mixture of $n$-butanol, $n$-propanol and $0.1 \mathrm{~N}-\mathrm{HCl}(1: 2: 1, \mathrm{v} / \mathrm{v})$ (solvent 1 ). $0.5 \mathrm{ml}$. fractions were collected. Serine and glycine could not be satisfactorily resolved with such a heavy load, and so proline, valine, serine and glycine were separated on columns loaded with $4 \mathrm{mg}$. of hydrolysate and developed with solvent $1,1 \mathrm{ml}$. fractions being collected. Finally, serine, glycine and arginine were separated on columns loaded with $2 \mathrm{mg}$. of hydrolysate and developed with solvent 1 until $36 \mathrm{ml}$. of solvent had emerged, when the solvent was changed to a mixture of $n$-propanol and $0 \cdot 5 \mathrm{~N}-\mathrm{HCl}(2: 1, \mathrm{v} / \mathrm{v})$ (solvent 2). $0.5 \mathrm{ml}$. fractions were collected. This method of analysing salmine, besides giving good resolution and optimum accuracy of estimation of the amino acids, enabled two chromatograms per week to be analysed. Two chromatography tubes of identical dimensions were used.

\section{Amino-acid estimations}

The amino-acid contents of all the fractions collected were estimated by a modification of the ${ }^{64} \mathrm{Cu}$ radiometric method of Blackburn \& Robson (1953). The three types of

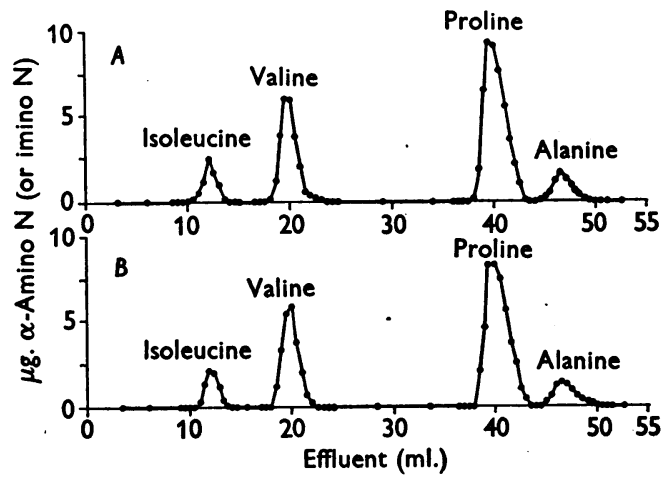

Fig. 1. $A$ : separation of isoleucine, valine, proline and alanine from a salmine sulphate hydrolysate on a $30 \times 0.9 \mathrm{~cm}$. starch chromatogram developing with solvent 1. Amino $\mathrm{N}$ (or imino $\mathrm{N}$ ) determined radiometrically. Total amino-acid load about $8 \mathrm{mg}$; $0.5 \mathrm{ml}$. fractions. $B$ : separation of DL-isoleucine, DL-Valine, DLproline and DL-alanine from a mixture of DL-isoleucine, DL-alanine, DL-valine, glycine, DL-proline, DL-serine and $L$-arginine made up in the molecular ratios

$$
1: 1: 3: 4: 6: 6: 48 \text {, }
$$

under the same chromatographic conditions as $A$ above.

fraction were treated as follows: (1) $0.5 \mathrm{ml}$. fractions of solvent 1 were neutralized and buffered by the addition of $2.5 \mathrm{ml}$. of a solution made up from 4 vol. of $0.18 \mathrm{M}-\mathrm{Na}_{2} \mathrm{HPO}_{4}$ and 1 vol. of $0.025 \mathrm{~N}-\mathrm{NaOH}$, and $1 \mathrm{ml}$. of radioactive copper phosphate suspension was added. (2) $3 \mathrm{ml}$. of a solution made up from 2 vol. of $0.27 \mathrm{M}-\mathrm{Na}_{2} \mathrm{HPO}_{4}$ and 1 vol. of $0.025 \mathrm{~N}-\mathrm{NaOH}$ were added to $1.0 \mathrm{ml}$. fractions of solvent 1 , followed by $2 \mathrm{ml}$. of radioactive copper phosphate suspension. (3) $0.5 \mathrm{ml}$. fractions of solvent 2 were neutralized and buffered by the addition of $2.5 \mathrm{ml}$. of a solution made up from 4 vol. of $0 \cdot 18 \mathrm{M}-\mathrm{Na}_{2} \mathrm{HPO}_{4}$ and 1 vol. of $0 \cdot 167 \mathrm{~N}-\mathrm{NaOH}$, and $1 \mathrm{ml}$. of radioactive copper phosphate suspension was added. The above mixtures gave only one liquid phase; they were thoroughly shaken and allowed to stand for $\mathbf{3 0} \mathrm{min}$. The subsequent filtration of the solutions and radiometric assay of the filtrates were carried out as described by Blackburn \& Robson (1953).

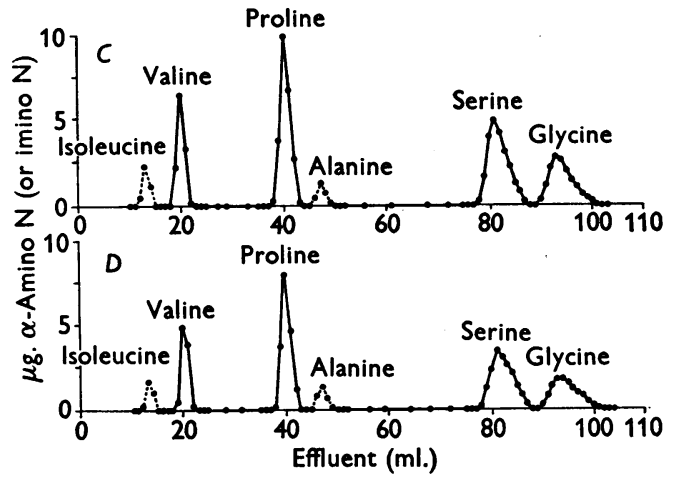

Fig. 2. $C$ : separation of isoleucine, valine, proline, aranine, serine, and glycine from a salmine sulphate hydrolysate on a $30 \times 0.9 \mathrm{~cm}$. starch chromatogram developing with solvent 1. Amino $\mathrm{N}$ (or imino $\mathrm{N}$ ) determined radiometrically. Total amino-acid load about $4 \mathrm{mg}$; $1.0 \mathrm{ml}$. fractions. $D$ : separation of DL-isoleucine, DL-valine, DL-proline, DL-alanine, DL-serine and glycine from the synthetic amino acid mixture used for $B$ (Fig. 1) under the same chromatographic conditions as $C$ above. Total amino-acid load about $3 \mathrm{mg}$.

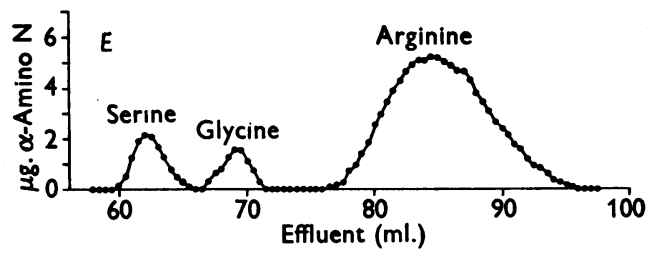

Fig. 3. $E$ : separation of serine, glycine and arginine from a salmine sulphate hydrolysate on a $30 \times 0.9 \mathrm{~cm}$. starch chromatogram, changing developer after $36 \mathrm{ml}$. from solvent 1 to solvent 2. Amino $\mathrm{N}$ determined radiometrically. Total amino-acid load about $2 \mathrm{mg}$.; $0.5 \mathrm{ml}$. fractions.

The activities, in counts/min., of the fractions were plotted against their fraction numbers to give ourves similar to those shown in Figs. 1-3. The average of four blank counts was determined, both before and after an amino acid peak where possible, and subtracted from the counts of those fractions contributing to the peak. The counts remaining, due to the copper-amino acid oomplex, were summed, and divided by the counts/min./ $\mu$ g. of $\alpha$-amino $N$ (or imino $N$ ) for the amino acid being estimated, to give the total amount of $\alpha$-amino $N$ in the amino acid peak. The counts/min./ $\mu \mathrm{g}$. of $\alpha$-amino $N$ (or imino $N$ ) for the amino acids estimated were derived from the mean difference in counts between four solutions containing $10 \mu \mathrm{g}$. of $\alpha$-amino $\mathrm{N}$ and four solution blanks. The reaction conditions for these solutions were the 
same as those for the column eluent fractions except for the small amount of $\mathrm{NaCl}$ formed by neutralization of the $\mathrm{HCl}$ in these fractions with $\mathrm{NaOH}$, which was omitted. Since both column blanks and 'standard blanks' gave the same counts when Gordon Slater starch was used for the columns, the effect of the $\mathrm{NaCl}$ was considered to be negligible.

The samples of glycine, DL-alanine, DL-valine, DL-proline, DL-serine, DL-isoleucine and L-arginine used as standards were tested by filter-paper chromatography and elementary analysis, and shown to be free from amino acid impurities and from ammonia, sulphate and halide ions.

\section{Decomposition of the amino acids of salmine during hydrolysis}

Rees (1946) has shown that serious losses of serine and threonine occur during the hydrolysis of proteins and, since serine is one of the constituent amino acids of salmine, experiments were carried out to determine the amounts of this and of any other amino acids lost during the hydrolysis of salmine.

$0 \cdot 2$ g. of glycine, DL-alanine, DL-valine, DL-isoleucine, DLserine, DL-proline and L-arginine were refluxed separately with $20 \mathrm{ml}$. of $5.5 \mathrm{~N}-\mathrm{HCl}$ for $24 \mathrm{hr}$., the $\mathrm{HCl}$ removed by vacuum distillation and the residues dissolved in $50 \mathrm{ml}$. of water. Suitable samples were taken from the solutions and their $\mathrm{NH}_{3}$ contents determined with the Markham (1942) apparatus, using a suspension of $\mathrm{Mg}(\mathrm{OH})_{2}$ to liberate the $\mathrm{NH}_{3}$. The amino-acid contents of other samples from the solutions were determined radiometrically by the ${ }^{64} \mathrm{Cu}$ method of Blackburn \& Robson (1953). Only serine and arginine decomposed under acid reflux, and the losses of these amino acids during the boiling with $5.5 \mathrm{~N}-\mathrm{HCl}$ of amino-acid mixtures made up to simulate salmine hydrolysates were estimated. The $\mathrm{NH}_{3}$ liberated during the hydrolysis of five $1 \mathrm{~g}$. amounts of salmine sulphate with $20 \mathrm{ml}$. of $5.5 \mathrm{~N}-\mathrm{HCl}$ for $24 \mathrm{hr}$. was determined. $\mathrm{No}_{\mathrm{NH}}$ was liberated from salmine sulphate itself on boiling with $\mathrm{Mg}(\mathrm{OH})_{2}$ suspension, nor from any of the amino acids used in these experiments.

\section{Total N}

The total $\mathrm{N}$ content of salmine sulphate was determined on an air-dried sample (Chibnall, Rees \& Williams, 1943). Suitable amounts of the same sample were weighed out at the same time for estimations of ash, moisture, and $\mathrm{SO}_{4}{ }^{2-}$ contents. The Kjeldahl procedure employed was that recommended by Chibnall et al. except that Se powder was substituted for sodium selenate. Digestion was for $16 \mathrm{hr}$. Six determinations were made.

\section{Ash}

A weighed sample of air-dried salmine sulphate was ashed at $800^{\circ}$ in a $\mathrm{Pt}$ crucible to constant weight. This gave the 'non-sulphated ash' weight. The ash was then treated with small successive amounts of $\mathrm{H}_{2} \mathrm{SO}_{4}$ and reheated to constant weight. This gave the weight of 'sulphated ash'.

\section{Moisture}

A weighed sample of air-dried s almine sulphate was' heated to constant weight in an oven at $102^{\circ}$.

\section{Sulphate}

The $\mathrm{SO}_{4}{ }^{2-}$ content of an air-dried sample of salmine sulphate was determined gravimetrically as $\mathrm{BaSO}_{4}$ by double decomposition with excess $\mathrm{BaCl}_{2}$ in water. Analyses were carried out in triplicate.

\section{Material and hydrolysis procedure}

The salmine sulphate used was supplied by Boots Pure Drug Co. Ltd., and had been prepared from the same batch of salmon milt as the sample previously analysed by Blackburn \& Robson (1953). Hydrolysates for amino acid analysis and $\mathrm{NH}_{3}$ determinations were prepared by refluxing $1 \mathrm{~g}$. samples with $15 \mathrm{ml}$. of $6 \mathrm{~N}-\mathrm{HCl}$ for $24 \mathrm{hr}$. $\mathrm{HCl}$ was removed in vacuo and the residue made up to $10 \mathrm{ml}$. with water.

\section{RESULTS}

A typical set of results obtained for the estimation of proline separated from a mixture of DL-isoleucine, DL-valine, DL-proline, DL-alanine, DL-serine, glycine and L-arginine, made up in the molecular ratios $1: 3: 6: 1: 6: 4: 48$, is shown in Table 1 . The amino acid mixture was made up to simulate a salmine hydrolysate as closely as possible. The estimation of proline is worked out in full from the data given in order to clarify the procedure adopted. The proline peak obtained from the data is that plotted in graph $B$ (Fig. 1), together with the peaks due to isoleucine, valine and alanine. In graph $A$ are plotted the peaks of the same four amino acids separated from a salmine sulphate hydrolysate under the same chromatographic conditions, and the close similarity of the two curves is obvious. Similarly, graphs $C$ and $D$ (Fig. 2) illustrate the parallelism which exists between the isoleucine, valine, alanine, proline, serine and glycine peaks of the hydrolysate and of the synthetic amino-acid mixture. Although the fractions comprising the isoleucine and alanine peaks were analysed in order to plot the curves, the results obtained were not sufficiently accurate to be used for the estimation of these amino acids, and the peaks are therefore drawn as dotted lines. Graph $E$ (Fig. 3) shows the resolution of the serine, glycine and arginine peaks.

Analyses of the seven amino acids separated from the synthetic mixture gave recoveries within the limits $100 \pm 3 \%$ for DL-isoleucine, DL-serine, DLalanine, glycine and L-arginine and $100 \pm 2 \%$ for DL-valine and DL-proline. These recoveries compare favourably with those obtained by Stein \& Moore (1948). Two salmine sulphate hydrolysates were analysed and the full results from the first hydrolysate are given in Table 2 together with mean values for five amino acids from the second hydrolysate. Although the alanine and glycine contents of this hydrolysate were not determined, we considered that the estimations for these five amino acids were sufficiently in accord with those obtained from the first hydrolysate to make further analyses unnecessary.

When the seven constituent amino acids of salmine were refluxed separately for $24 \mathrm{hr}$. with 
Table 1. Analysis of proline fractions separated from a 1:4:6:1:6:4:48 (mol. prop.) mixture of DLisoleucine, DL-valine, DL-proline, DL-alanine, DL-serine, glycine and L-arginine on starch chromatogram developed with solvent 1. (See Fig. 1, B)

(The calculation of the amount of proline is as follows: activity of $1 \mu \mathrm{g}$. of imino $\mathrm{N}$ (proline standard) $=443 \cdot 0-74 \cdot 6=368 \cdot 4$ counts/min., therefore imino $N$ in fractions $77-86$ is $16730 / 368 \cdot 4=45 \cdot 4 \mu \mathrm{g}$.; imino $\mathrm{N}$ (proline) applied to chromatogram $=44.8 \mu \mathrm{g}$. Recovery, $101 \cdot 4 \%$.)

\begin{tabular}{|c|c|c|c|c|c|}
\hline \multicolumn{2}{|c|}{$\begin{array}{l}\text { Activities of proline } \\
\text { standards and blanks }\end{array}$} & \multicolumn{4}{|c|}{ Starch chromatogram no. 23 proline fractions } \\
\hline $\begin{array}{c}\text { Imino } N \\
\text { (proline) } \\
(\mu \mathrm{g} .)\end{array}$ & $\begin{array}{c}\text { Activity } \\
\text { (counts/min.) }\end{array}$ & $\begin{array}{c}\text { Fraction } \\
\text { no. }\end{array}$ & $\begin{array}{c}\text { Activity } \\
\text { (counts/min.) }\end{array}$ & $\begin{array}{l}\text { Counts/min. } \\
\text { (less average } \\
\text { blank) }\end{array}$ & $\begin{array}{c}\text { Amount of } \\
\text { proline } \\
(\mu \mathrm{g} . \text { imino } N)\end{array}$ \\
\hline $\begin{array}{l}10 \cdot 0(1) \\
10 \cdot 0(2) \\
10 \cdot 0(3) \\
10 \cdot 0(4)\end{array}$ & $\begin{array}{l}4460 \\
4420 \\
4440 \\
4400\end{array}$ & $\begin{array}{l}73^{*} \\
74^{*} \\
75^{*} \\
76^{*}\end{array}$ & $\begin{array}{l}768 \\
732 \\
739 \\
749\end{array}$ & $\begin{array}{r}24 \\
-12 \\
-5 \\
5\end{array}$ & $\begin{array}{l}- \\
-\end{array}$ \\
\hline Average & 4430 & $\begin{array}{l}77 \\
78\end{array}$ & $\begin{array}{l}1595 \\
2502\end{array}$ & $\begin{array}{r}851 \\
1758\end{array}$ & $\begin{array}{l}2 \cdot 32 \\
4 \cdot 77\end{array}$ \\
\hline $\begin{array}{c}\text { Blanks } \\
\text { (1) } \\
(2) \\
(3) \\
(4)\end{array}$ & $\begin{array}{l}727 \\
757 \\
752 \\
\mathbf{7 4 8}\end{array}$ & $\begin{array}{l}79 \\
80 \\
81 \\
82 \\
83 \\
84 \\
85\end{array}$ & $\begin{array}{l}3803 \\
3819 \\
3506 \\
2894 \\
2162 \\
1743 \\
1183\end{array}$ & $\begin{array}{r}3059 \\
3075 \\
2762 \\
2150 \\
1418 \\
999 \\
439\end{array}$ & $\begin{array}{l}8 \cdot 32 \\
8 \cdot 35 \\
\mathbf{7} \cdot 53 \\
5 \cdot 85 \\
3 \cdot 85 \\
2 \cdot 72 \\
1 \cdot 18\end{array}$ \\
\hline \multirow[t]{2}{*}{ Average } & 746 & 86 & 963 & 219 & $0 \cdot 60$ \\
\hline & & $\begin{array}{l}87^{*} \\
88^{*} \\
89^{*}\end{array}$ & $\begin{array}{l}749 \\
761 \\
708\end{array}$ & $\begin{array}{r}5 \\
17 \\
-36\end{array}$ & E \\
\hline
\end{tabular}

* Average column blank (tubes 73-76 and 87-89 inclusive) =744 counts $/ \mathrm{min}$.

Table 2. Analyses of the amino acids in a salmine sulphate hydrolysate

Starch chromatogram

no.
9
12
13
14
16
17
18
20
21

Mean values

Mean values

for second

hydrolysate

(g. amino acid/100 g. salmine) (see text)

\begin{tabular}{|c|c|c|c|c|c|c|}
\hline Isoleucine & Alanine & Valine & Glycine & Serine & Proline & Arginine \\
\hline $1 \cdot 30$ & 0.87 & $3 \cdot 72$ & - & - & 6.95 & - \\
\hline 1.27 & 0.88 & $\mathbf{3 \cdot 6 5}$ & - & - & $6 \cdot 80$ & - \\
\hline 1.27 & 0.91 & 3.70 & - & - & 6.93 & - \\
\hline - & - & $\mathbf{3 \cdot 6 6}$ & $3 \cdot 12$ & $6 \cdot 19$ & 6.94 & - \\
\hline - & - & 3.66 & 2.95 & $6 \cdot 19$ & 6.90 & - \\
\hline \multicolumn{4}{|c|}{ Unfinished chromatogram } & $6 \cdot 40$ & - & - \\
\hline \multirow{3}{*}{ - } & - & - & 3.01 & $6 \cdot 31$ & - & $85 \cdot 8$ \\
\hline & - & - & 2.98 & $6 \cdot 33$ & - & 87.5 \\
\hline & \multicolumn{3}{|c|}{ Arginine only determined } & & & $86 \cdot 0$ \\
\hline 1.28 & 0.89 & $3 \cdot 67$ & 3.01 & $6 \cdot 28$ & 6.90 & 86.4 \\
\hline $1 \cdot 27$ & - & 3.68 & - & $6 \cdot 28$ & 6.87 & 86.5 \\
\hline
\end{tabular}

5.5N-hydrochloric acid only serine and arginine decomposed to give ammonia. Radiometric analyses of the residual amounts of all seven amino acids after refluxing showed that only serine decomposed by more than $2 \%$. The percentage loss of serine as measured by the ammonia liberated was found to be $8.9 \%$, and as measured by the radiometric copper method $9 \pm 1 \%$. The ammonia liberated by arginine corresponded to a loss of $0.31 \%$, assuming $1 \mathrm{~mol}$. of arginine to give $1 \mathrm{~mol}$. of ammonia on decomposition, and this loss could not be detected by the radiometric assay. When mixtures of glycine, alanine, valine, isoleucine, serine, proline and arginine in the molecular ratios of (a) $4: 1: 3: 1: 0: 6: 50$ and $(b) 4: 1: 3: 1: 7: 6: 50$ were refluxed for $24 \mathrm{hr}$. with $5 \cdot 5 \mathrm{~N}$-hydrochloric acid the average losses of serine and arginine, as measured by the ammonia liberated, were 8.7 and $0.30 \%$ respectively. It was assumed that the loss of arginine in mixture $(b)$ was the same as that in 
mixture $(a)$, i.e. $0 \cdot 30 \%$. Mixture (a) was made up to simulate salmine less its serine, and mixture $(b)$ the complete salmine.

The mean of five determinations for the amount of ammonia liberated during hydrolysis of salmine sulphate was $0.204 \pm 0.003 \mathrm{~g} . / 100 \mathrm{~g}$. salmine, the lowest and highest amounts observed being $0 \cdot 193$ and $0.218 \mathrm{~g} . / 100 \mathrm{~g}$. salmine respectively. The amount of ammonia expected from the serine, assuming that it decomposes in the protamine at the same rate as it does in the free state, is $0.0904 \mathrm{~g}$. and that from arginine $0.0262 \mathrm{~g}$., giving a total of 0.117 g. $/ 100$ g. salmine. From these figures it seems clear that either serine or arginine (or both) decompose at a more rapid rate when combined in the protamine than they do in the free state. Rees (1946) refluxed salmine with $20 \%$ hydrochloric acid for $24 \mathrm{hr}$. and found the liberated ammonia to be $0 \cdot 15 \mathrm{~g} . / 100 \mathrm{~g}$. salmine (figure calc. from Table 6 of his paper). Using his correction factor of 100/89.5 for serine he states that the whole of this ammonia can be accounted for as being due to serine decomposition. However, he has made it clear that for all the proteins he analysed his correction factors for serine and threonine cannot account for all the ammonia found after hydrolysis, and states that this may be due to serine and threonine decomposing more rapidly when combined in the protein than in the free state. In arriving at our correction factors for serine and arginine decomposition during the hydrolysis of salmine sulphate we have assumed that the ratio of the rates of decomposition of the two amino acids when combined are the same as in the free state. Whether this is in fact the case it is impossible to say, but it is the only reasonable assumption that can be made. On this basis the fraction of ammonia found in salmine hydrolysates due to decomposition of serine is $0.164 \mathrm{~g} . / 100 \mathrm{~g}$. salmine $(80 \%$ of the total), equivalent to a serine loss of $1.01 \mathrm{~g} . / 100 \mathrm{~g}$. salmine, and corresponding to a correction factor of $100 / 86$. Hence the observed serine amount of $6 \cdot 28 \mathrm{~g} . / 100 \mathrm{~g}$. salmine is corrected to $7 \cdot 29 \mathrm{~g} . / 100 \mathrm{~g}$. salmine. The corresponding correction factor of $100 / 99 \cdot 5$ for arginine has not been applied since the arginine assay is not sufficiently accurate to warrant its use.
The total nitrogen content of moisture-free salmine sulphate was $24 \cdot 3 \%$, and its sulphate content $20.5 \%$. The ash content was $1.55 \%$ and the 'sulphated' ash content $1 \cdot 70 \%$. A semiquantitative analysis of the 'non-sulphated' ash showed that it contained about $15 \%$ of calcium, $35 \%$ of sulphate, and appreciable amounts of phosphate. Allowing for the percentage of 'non-sulphated' ash and for the sulphate content of salmine sulphate, we assumed the total nitrogen content of free salmine to be $31.1 \%$, and the above data are reported in terms of this hypothetical free base.

\section{DISCUSSION}

The analytical results obtained in the present work show that, within the limits of the methods used ( $\pm 3 \%$ ) the amino acids isoleucine, alanine, valine, glycine, proline, serine and arginine occur in salmine in the molecular ratios shown in Table 3, and that the minimum molecular weight of the protamine, if it is homogeneous, is about 10000 .

We have pointed out in the introduction to this paper that the analyses of previous workers show fairly good agreement for the amounts of arginine and glycine in salmine; our own analyses are in accord with their figures (Table 4). Estimates of the other five amino acids do not show good overall agreement, although there may be agreement between two or more sets of authors for any particular amino acid. These differences become more apparent when the estimated minimum molecular weight for salmine, and the number of residues of each of its constituent amino acids, are calculated from the amino-acid analyses. From his analysis of the protamine, Tristram (1947) gave the minimum molecular weight as 8000 and found that the ratios of isoleucine, alanine, valine, glycine, proline, serine and arginine were $1: 1: 2: 3: 4: 7: 40$, but Velick \& Udenfriend (1951) found that alanine, valine, glycine, proline, serine and arginine occur in the ratios $1: 3: 3: 4: 4: 34$ and gave a value of 7000 for the minimum molecular weight. The last-named authors have pointed out that, whilst the analytical discrepancies may be due to differences in methods of analysis it is also possible that they may be

Table 3. Molecular proportions of amino acids of salmine

\begin{tabular}{|c|c|c|c|c|c|}
\hline Amino acid & $\begin{array}{c}\text { Amino acid } \\
\mathrm{N} \text { as } \% \\
\text { total } \mathrm{N}\end{array}$ & $\begin{array}{c}\text { Amino acid/ } \\
100 \mathrm{~g} . \\
\text { salmine }\end{array}$ & $\begin{array}{c}\text { Minimum } \\
\text { mol.wt. }\end{array}$ & $\begin{array}{l}\text { No. of } \\
\text { residues }\end{array}$ & $\begin{array}{c}\text { Calculated } \\
\text { mol.wt. }\end{array}$ \\
\hline Isoleucine & $0 \cdot 44$ & $1 \cdot 28$ & 10240 & 1 & 10240 \\
\hline Alanine & 0.45 & $0 \cdot 89$ & 10000 & 1 & 10000 \\
\hline Valine & $1 \cdot 40$ & $3 \cdot 68$ & 3190 & $\mathbf{3}$ & 9570 \\
\hline Glycine & 1.80 & 3.01 & 2500 & 4 & 10000 \\
\hline Serine & $3 \cdot 12$ & $7 \cdot 29$ & 1440 & 7 & 10080 \\
\hline Proline & $2 \cdot 70$ & 6.90 & 1670 & 6 & 10020 \\
\hline Arginine & $89 \cdot 80$ & $86 \cdot 40$ & 202 & 50 & 10100 \\
\hline Total & $99 \cdot 71$ & $109 \cdot 44$ & & 72 & \\
\hline
\end{tabular}


Table 4. Amino acid analyses of salmine by various authors

\begin{tabular}{|c|c|c|c|c|c|c|c|c|c|}
\hline \multirow[b]{3}{*}{ Amino acid } & \multicolumn{9}{|c|}{$\mathrm{N}$ as $\%$ total $\mathrm{N}$ of protamine } \\
\hline & \multirow[b]{2}{*}{$\begin{array}{c}\text { Mills } \\
\text { (1952) }\end{array}$} & \multirow[b]{2}{*}{$\begin{array}{c}\text { Tristram } \\
\text { (1947) }\end{array}$} & \multirow[b]{2}{*}{$\begin{array}{c}\text { Hamer \& } \\
\text { Woodhouse } \\
(1949)\end{array}$} & \multirow[b]{2}{*}{$\begin{array}{l}\text { Block } \\
\text { et al. } \\
(1949)\end{array}$} & \multicolumn{3}{|c|}{ Velick \& Udenfriend (1951) } & \multirow[b]{2}{*}{$\begin{array}{c}\text { Blackburn } \\
\text { \& Robson } \\
\text { (1953) }\end{array}$} & \multirow[b]{2}{*}{$\begin{array}{c}\text { Present } \\
\text { work }\end{array}$} \\
\hline & & & & & $\overbrace{\text { Mioro- }}^{\text {biogical* }}$ & Isotope & $\underset{\substack{\text { Ion- } \\
\text { exchange }}}{\mid}$ & & \\
\hline Arginine & $90 \cdot 6$ & $89 \cdot 0$ & $91 \cdot 0$ & $90 \cdot 4$ & - & - & $86 \cdot 3$ & $90 \cdot 6$ & $89 \cdot 8$ \\
\hline Isoleucine & 1.85 & 10.56 & 0.62 & 0.41 & - & 一 & - & 0.45 & 0.44 \\
\hline Valine & $1 \cdot 85$ & $\{1 \cdot 20$ & $1 \cdot 47$ & $1 \cdot 56$ & $1 \cdot 65$ & 1.92 & 1.81 & $1 \cdot 44$ & $1 \cdot 40$ \\
\hline Glycine & 1.97 & $1 \cdot 78$ & $2 \cdot 17$ & 1.96 & - & $1 \cdot 89$ & 1.90 & - & $1 \cdot 80$ \\
\hline Alanine & 0.59 & 0.56 & $0 \cdot 30$ & 0.75 & - & 0.58 & 0.55 & - & 0.45 \\
\hline Proline & $2 \cdot 16$ & $2 \cdot 29$ & 1.96 & $\begin{array}{c}3.06 \text { to } \\
\mathbf{3} \cdot 33\end{array}$ & $2 \cdot 50$ & $2 \cdot 62$ & $2 \cdot 70$ & - & $2 \cdot 70$ \\
\hline Serine & $2 \cdot 70$ & $3 \cdot 94$ & $2 \cdot 41$ & $2 \cdot 96$ & $3 \cdot 64$ & $2 \cdot 74$ & $2 \cdot 70$ & 一 & $3 \cdot 12$ \\
\hline
\end{tabular}

accounted for by differences in origin of the salmine samples. They claim, however, that the salmine used seemed to be homogeneous from the data obtained from its sedimentation and electrophoretic mobility; that, whilst salmine may be a family of closely related peptides, this is not very probable in view of the fact that all the amino ends of the chains terminate in proline and that the ratio of monoamino acids to arginine cannot be a structural variant since the protamine is electrically homogeneous. Recently, however, Felix (1952) has stated that there is good evidence that protamines are not homogeneous, but consist of several components with very similar composition but different molecular size, ranging probably from 2000 to 10000 . He cites the case of clupeine from which about ten components were separated by means of countercurrent distribution. The data on the amino acid composition of salmine obtained in the present work do not prove conclusively that the salmine sample analysed was homogeneous, but the fact that the amino acid residues occur in integral ratios within the limits of experimental error is evidence in favour of homogeneity.

\section{SUMMARY}

1. A complete amino acid analysis of a specimen of salmine sulphate has been made.

2. The losses of serine and arginine during the acid hydrolysis of salmine sulphate have been experimentally assessed; the serine loss was estimated to be $14 \%$ and the arginine loss $0.5 \%$.

3. The amino acids isoleucine, alanine, valine, glycine, proline, serine and arginine were found to occur in selmine in the molecular proportions $1: 1: 3: 4: 6: 7: 50$. On this basis the minimum molecular weight of salmine was calculated to be about 10000 if the protamine is a single substance.

4. The problem as to whether salmine may be regarded as a single substance has been discussed briefly in the light of available analytical data.

We are indebted to Miss B. Skinner for considerable assistance with the experimental work, and to Messrs $R$. Gibson, S. Dilworth and G. H. Hines for the design and construction of the fraction cutter. Our thanks are also due to Dr A. J. P. Martin, F.R.S., and Dr F. O. Howitt for helpful advice and criticism during the course of this work, and to the Director and Council of the Wool Industries Research Association for permission to publish this paper.

\section{REFERENCES}

Blackburn, S. \& Robson, A. (1953). Biochem. J. 54, 295.

Block, R. J., Bolling, D., Gershon, H. \& Sober, A. (1949). Proc. Soc. exp. Biol., N.Y., 70, 494.

Chibnall, A. C., Rees, M. W. \& Williams, E. F. (1943). Biochem. J. 37, 354.

Felix, K. (1952). Ciba Symp. Abstr., December 1952.

Hamer, D. H. \& Woodhouse, D. L. (1949). Nature, Lond., 163, 689 .
Markham, R. (1942). Biochem. J. 36, 790.

Mills, G. L. (1952). Biochem. J. 50, 707.

Rees, M. W. (1946). Biochem. J. 40, 632.

Stein, W. H. \& Moore, S. (1948). J. biol. Chem. 176, 337.

Tristram, G. R. (1947). Nature, Lond., 160, 637.

Velick, S. F. \& Udenfriend, S. (1951). J. biol. Chem. 191, 233. 